
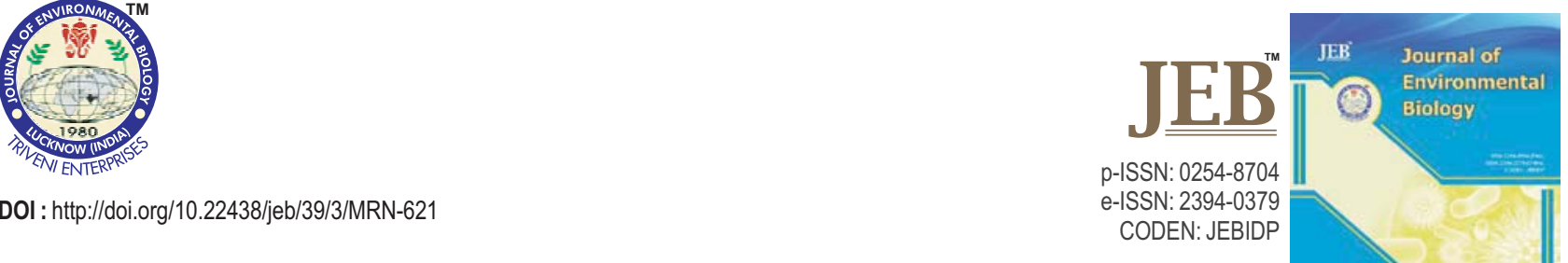

\title{
Taxonomy and effect of temperature, nutrients and light intensity on the growth of two freshwater algal species of Raphidophyceae new to Korea
}

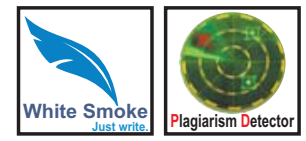

\section{Authors Info}

\section{H. Chae, B.Y. Jo and H.S. Kim*}

School of Life Sciences, Kyungpook National University, Daegu, 41566, Korea

*Corresponding Author Email : kimhsu@knu.ac.kr

Key words

Environmental factors Gonyostomum species Growth characteristics ITS rDNA

Publication Info Paper received :23.03.2017 Revised received: 01.06 .2017 Re-revised received: 01.08 .2017 Accepted: 15.09.2017

\begin{abstract}
Aim : The present study was conducted to understand the taxonomy and effect of environmental factors on the growth of two freshwater algal Raphidophyceae (Gonyostomum depressum and G. semen) that are new to Korea.
\end{abstract}

Methodology : Samples used in the culture experiments were isolated from two small ponds in Jeju Island and Kyungpook province of Korea. Species identification was based on morphology and nuclear internal transcribed spacer (ITS) sequences of rDNA. The growth characteristics of these species through the effect of temperature, nitrate concentration and light intensity were investigated.

Results : These two species have different cell shape, size and caudus morphology. The nuclear ITS rDNA sequences of specimens had $99 \%$ identity with $G$. depressum and $G$. semen recorded at GenBank. Gonyostomum depressum had the highest growth rate at $21^{\circ} \mathrm{C}$, nitrate concentration of 1,000 $\mu \mathrm{M}$, and light intensity of 120 $\mu \mathrm{mol}$ photons $\mathrm{m}^{-2} \mathrm{~s}^{-1}$. G. semen showed the highest growth rate at $21^{\circ} \mathrm{C}, 120 \mu \mathrm{mol}$ photons $\mathrm{m}^{-2} \mathrm{~s}^{-1}$ and nitrate concentration of $100 \mu \mathrm{M}$, respectively.

Interpretation : Water temperature seems to be important in controlling the distribution and growth of $G$. depressum and G. semen.
- To understand taxonomy and growth characteristics of two species of Raphidophyceae

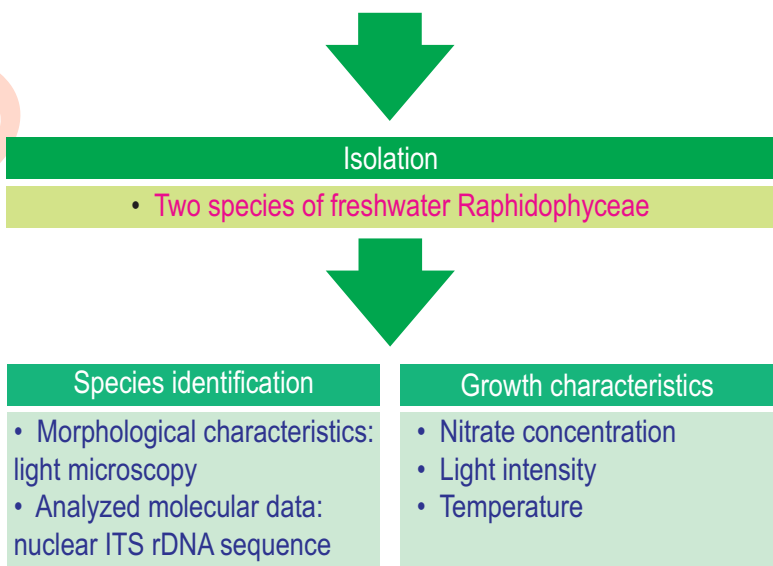
nuclear ITS rDNA sequence

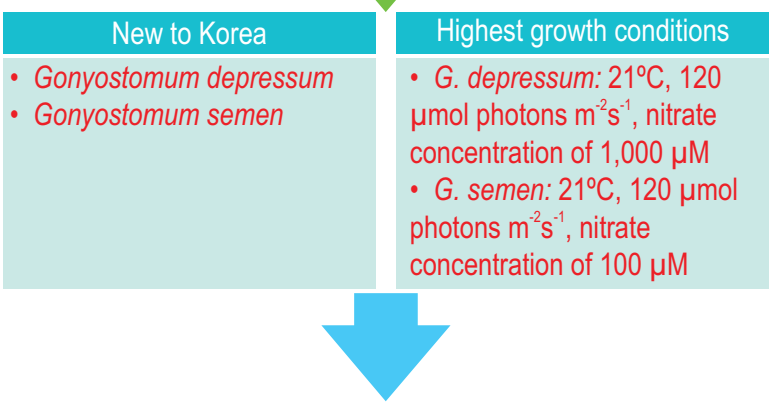

- Variable factors seem to control the distribution and growth that are new to Korea of G. depressum and G. semen 


\section{Introduction}

Raphidophyceae is a small group of marine and freshwater unicellular biflagellate algae that lack cell wall. The three freshwater Raphidophyceae genera (Gonyostomum Diesing, Merotrichia Mereschkowsky and Vacuolaria Cienkowski) are distinguished by the position of the flagella and shape of the trichocyst. Previous studies have been carried out on freshwater algae from Korea (Kim et al., 2009; Kim 2013 a, b, c; Kim, 2014 a, b), but there are very few contributions on freshwater Raphidophyceae from Korea because these algae burst after fixation due to lack of cell walls (Cronberg, 2005; Figueroa and Rengefors, 2006). Recently, two species of genus Gonyostomum Diesing (G. depressum and G. semen) of Raphidophyceae, have been discovered in various water bodies of Korea such as acidic mountainous wet lands, old shallow reservoirs and lowland mesotrophic swamps, and also their morphology and growth characteristics in vitro have been studied.

Five species of the genus Gonyostomum Diesing 1866 have elliptical or obovoid cells, two apical flagella, a triangular or circular gullet and a needle-shaped trichocysts (Guiry and Guiry, 2017). Most species have worldwide distribution and these species mainly occur in acidic waters (Kusber, 2003; Hu and Wei, 2006; Menezes and Bicudo, 2010).

The shape of Gonyostomum cells simple, easily deformable and has limited diagnostic characters, due to which it is difficult to differentiate the species belonging to this genus. Thus, species identification and placement within the Raphidophyceae family can be safely done by analyzing the nuclear internal transcribed spacer (ITS) sequence of rDNA (Lebret et al., 2015, sub "G. latum").

G. depressum and G. semen tend to favor small, humic and slightly acidic water bodies that are brown in color and mesotrophic. However, previous studies indicate that they are distributed in environments with wide range of nutrients (total phosphorus 0.004-1.960 $\mathrm{mg} \mathrm{l}^{-1}$ and ammonium 0-1.700 $\left.\mathrm{mg} \mathrm{l}^{-1}\right), \mathrm{pH}$ (4.70-9.30), temperature $\left(6.0-30.7^{\circ} \mathrm{C}\right)$ and water colour (Schmidt and Kusel-Fetzmann, 1999; Rengefors et al., 2012).

G. semen is distributed in most of the phytoplankton biomass during late summer in humic lakes of northern Europe (Salonen and Rosenberg, 2000). Previous studies have reported blooms of this species in various habitats, such as humic lakes, non-colored oligotrophic lakes, large and deep reservoirs, rivers and small eutrophic flood plains throughout the Europe (Korneva, 2000; Negro et al., 2000; Hehmann et al., 2001; Pęczuła, 2007). This species has become more widespread in the lakes of Scandinavia, where the blooms have a significant negative impact (Rengefors et al., 2012). Numerous studies have examined the factors that may affect blooming of this species (Salonen and Rosenberg, 2000; Pęczuła, 2007; Trigal et al.,
2011; Rengefors et al., 2012). There is no previous study on the growth characteristics of the species belonging to genus Gonyostomum using culture experiments.

In view of the above, the present study was carried out to identify and characterize two new algal species from small ponds in Korea. The growth of two identified algal species were also studied under the effect of temperature, nitrate and light.

\section{Materials and Methods}

Gonyostomum depressum and G. semen, used in the culture experiment, were isolated by pipetting from the water samples that were collected from two small ponds in Jeju island $\left(33^{\circ} 22 ' \mathrm{~N}, 126^{\circ} 41^{\prime} \mathrm{E}\right)$ and Kyungpook province $\left(36^{\circ} 23^{\prime} \mathrm{N}, 128^{\circ}\right.$ $\left.28^{\prime} \mathrm{E}\right)$ of Korea. Species identification was performed using a light microscope (Zeiss, Imager. A2) equipped with differential interference contrast (DIC) optics and by determination of nuclear ITS rDNA sequence. Photomicrographs were taken with an AxioCam HRC camera (Zeiss, Germany).

DNA extraction, PCR amplification, PCR product purification and sequence alignment were conducted following Jo et al. (2011) and Jo et al. (2013). Amplification of ITS (ITS1-5.8SITS2) was performed using primer pairs 4618F and LSU1R and 4618F and ITSF/R (Bowers et al., 2006). Nuclear ITS sequences were used as barcodes to identify the species. BLAST was used to determine the most similar sequences available in public databases.

The unialgal stock cultures were maintained in DYIII medium with MES (2-[N-morpholino] ethanesulfonic acid) and modified WC culture medium (MWC) buffered to $\mathrm{pH} 7.0$, at $21 \pm 1$ ${ }^{\circ} \mathrm{C}$ and a light intensity of approximately $80 \mu \mathrm{mol}$ photons $\mathrm{m}^{-2} \mathrm{~s}^{-1}$ (cool white fluorescent light) on a $16 \mathrm{hr}$ light : $8 \mathrm{hr}$ dark cycle. For growth temperature experiments, each species was cultured in DYIII medium at $12^{\circ} \mathrm{C}, 15^{\circ} \mathrm{C}, 18^{\circ} \mathrm{C}, 21^{\circ} \mathrm{C}, 24^{\circ} \mathrm{C}$ and $27^{\circ} \mathrm{C}$, respectively, $80 \mu \mathrm{mol}$ photons $\mathrm{m}^{-2} \mathrm{~s}^{-1}$ of continuous white fluorescent light at pH 7.0. Experiments on the effect of nitrate concentration and light intensity were carried out at $21^{\circ} \mathrm{C}$ (the maximum growth rate for each species). For nitrate experiments, cells were selected from the stock cultures in exponential growth phase, adapted to nutrient-limited MWC culture medium for one week, and then inoculated into fresh media under $80 \mu \mathrm{mol}$ photons $\mathrm{m}^{-2} \mathrm{~s}^{-1}$ of continuous white fluorescent at $21^{\circ} \mathrm{C}$ and $\mathrm{pH}$ 7.0. For the light intensity experiments, cells were cultured in MWC medium at $20,40,80$ and $120 \mu \mathrm{mol}$ photons $\mathrm{m}^{-2} \mathrm{~s}^{-1}$ of continuous white fluorescent light at $21^{\circ} \mathrm{C}$ and $\mathrm{pH} 7.0$.

All the experiments were conducted in triplicate in $125 \mathrm{ml}$ Erlenmeyer flasks after adaptation for one week at selected temperature, nitrate concentration and light intensity on a $16 \mathrm{hr}$ light : $8 \mathrm{hr}$ dark cycle and then inoculated into fresh media at an initial cell density of approximately 200 or 400 cells ml-1. Samples 
were fixed with Lugol's solution and the cell number was determined using a Sedgwick Rafter chamber. Growth rates is expressed as $\mu=\left[\left(\ln \left(\mathrm{N}_{2}\right)-\ln \left(\mathrm{N}_{1}\right)\right] /\left(\mathrm{t}_{2}-\mathrm{t}_{1}\right)\right.$, where $\mathrm{N}_{2}$ and $\mathrm{N}_{1}$ are the number of cells during the period of exponential growth at times $\mathrm{t}_{2}$ and $t_{1}$. Specific growth rates were calculated during the exponential growth periods specific for each species between day 0 and days 12,15 or 24 .

\section{Results and Discussion}

The morphology of representative $G$. depressum cells are shown in Fig. 1 (A-F). These cells were ovoid or round, sometimes angulate, 27.8-41.4 $\mu \mathrm{m}$ long and 24.3-34.2 $\mu \mathrm{m}$ wide, and were also deformable and fragile. The apical area of the cell was slightly twisted. There were many yellowish green and discoid chloroplasts. The gullet was triangular and there were needle-like trichocysts distributed radially along the margin of the cell, below the cell membrane.

G. semen is typically obovoid or obpyriform, sometimes lanceolate, 45-84 $\mu \mathrm{m}$ long and 27-42 $\mu \mathrm{m}$ wide and slightly deformable and fragile (Fig. 1G-L). Each cell has a somewhat pointed caudus at the posterior end, numerous long and rod-like trichocysts, concentrated on the poles and some trichocysts irregularly distributed in the cytoplasm. There are many yellowish green and discoid chloroplasts. The gullet is triangular. The present study has recorded two freshwater algal Raphidophyceae in Korea, represented by Gonyostomum depressum and G. semen for the first time. Although, these species possess variable and deformable shapes with wide range of dimensions, the morphology and dimensions of specimens were similar to previously identified specimens of $G$. depressum (Lauterborn) Lemmermann and $G$. semen (Ehrenberg) Diesing.

The nuclear ITS rDNA sequences of $G$. depressum (GenBank Accession number; KX671119) and G. semen (GenBank Accession number; KX671120) isolates in this study had 662 and 756 nucleotides, respectively. G. depressum strain had $99.6 \%$ sequence similarity to G. latum NIES1808 (GenBank Accession number; KP230804) and G. semen strain had 99.9\% sequence similarity to G. semen BO32 clone 12 (GenBank Accession number; KP230768). The molecular data from nuclear ITS rDNA sequences of specimens (KNUGMS16 and KNUGGR06) had more than $99 \%$ similarity with Gonyostomum depressum and G. semen recorded in GenBank (GenBank Accession number; KP230804, sub. "G. latum" and KP230768). Kusber (2003) regarded G. depressum and G. latum as conspecific, under the name $G$. depressum. In present study, specimen (KNUGMS16 strain) identified $G$. depressum according to the taxonomic assessment.

The population growth of unialgal cultures of $G$. depressum and G. semen at $12-27^{\circ} \mathrm{C}$ was studied (Fig. 2). G. depressum had a greater growth rate than $G$. semen at all temperatures, but very low growth at $12^{\circ} \mathrm{C}$ (Fig. 2). At $15^{\circ} \mathrm{C}$, the cell count of $G$. depressum rapidly increased after a lag phase of 15 days, and the maximum cell count was at 36 days (Fig. 2A). In addition, the growth rate of $G$. depressum was greater at all tested temperatures (Fig. 3A).

The effects of nitrate concentration on the population growth of G. depressum and G. semen are shown in Fig. 4. Although the maximum population growth of $G$. depressum was at 1,000 $\mu \mathrm{M}$, growth at all nitrate concentrations was similar until ninth day (Fig. 4A). The growth rate increased as the nitrate concentration increased over the experiment concentrations (Fig. 3B).

G. semen had similar population growth at all nitrate concentrations until $21^{\text {st }}$ day. The maximum population growth and growth rate were found at $100 \mu \mathrm{M}$ (Fig. 3B and 4B), but growth rate was similar at all the tested nitrate concentrations (Fig. 3B).

The effect of different light intensities on the population growth of G. depressum and G. semen at $21^{\circ} \mathrm{C}$ is shown in Fig. 5 . Both the species exhibited growth at all tested light intensities, but population growth and growth rate of both species were
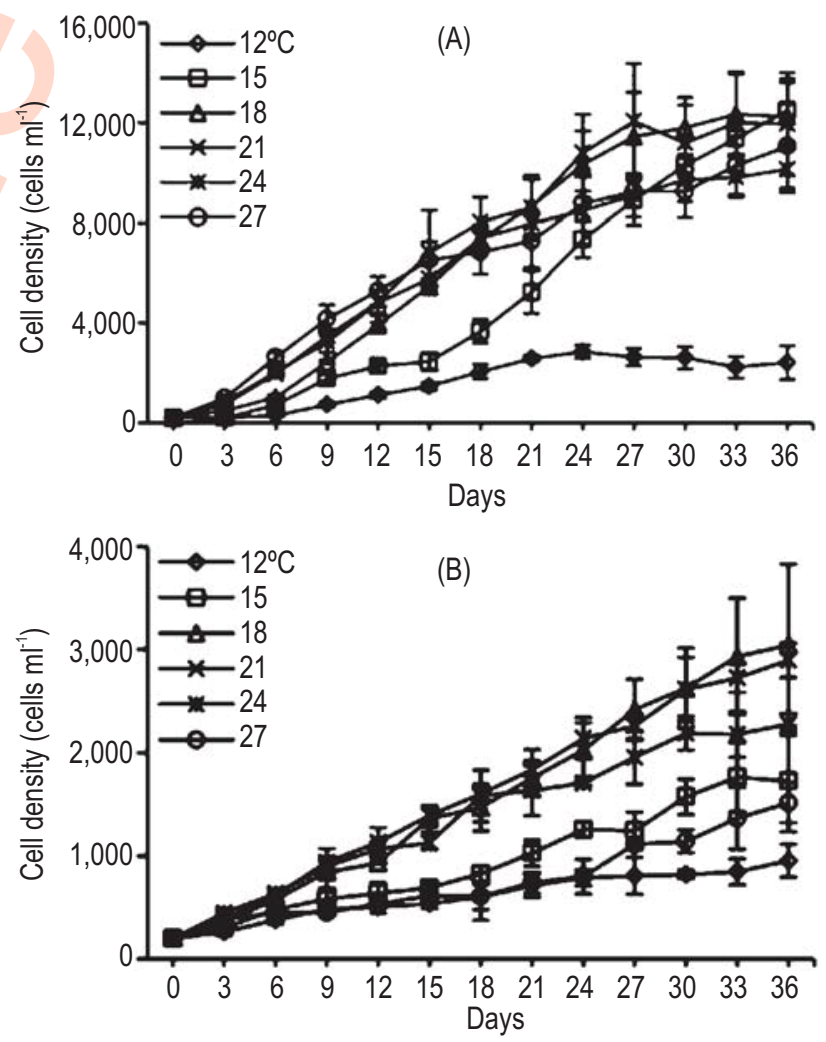

Fig. 2 : Population growth of $G$. depressum (A) and G. semen (B) at different temperatures. Symbols indicate means and bars indicate maximum and minimum values from three experiments 

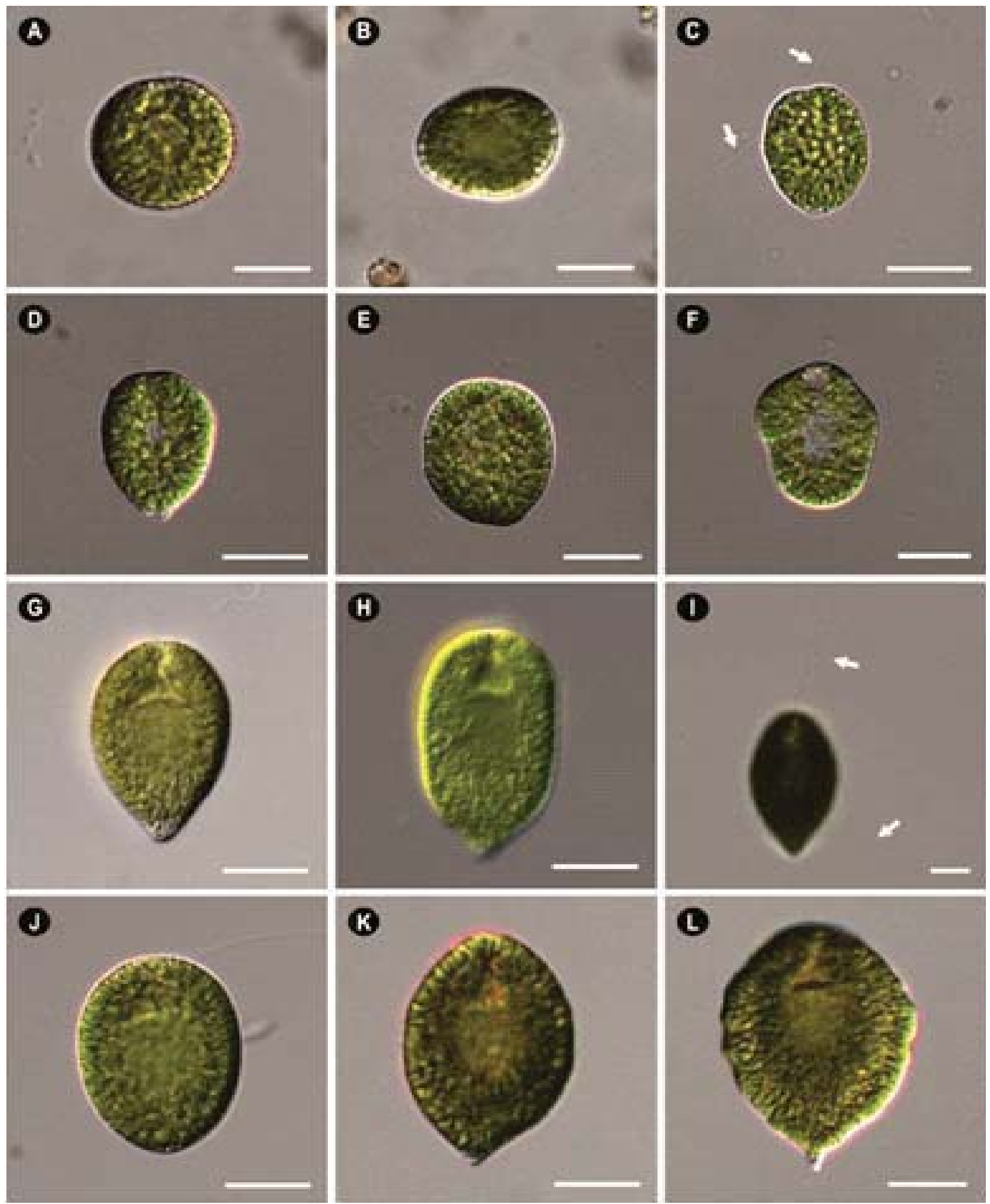

Fig. 1 : Light micrographs of various G. depressum (A-F) and G. semen (G-L) cells. (A) round cell, (B) oval cell, leaning to one side, (C) oval cell with 2 heterodynamic flagella (arrows), (D) oval cell with discoid chloroplasts, (E) posterior pole truncate cell with rod-shaped trichocysts radially distributed in the cytoplasm, (F) deformable cell. (G) obovoid cell, (H) cell with trichocysts, (I) obovoid cell with 2 heterodynamic flagella (arrows), (J) the obscure shape, (K) ovate cell, (L) cell observed in old culture medium. Scale bars: 20 m 

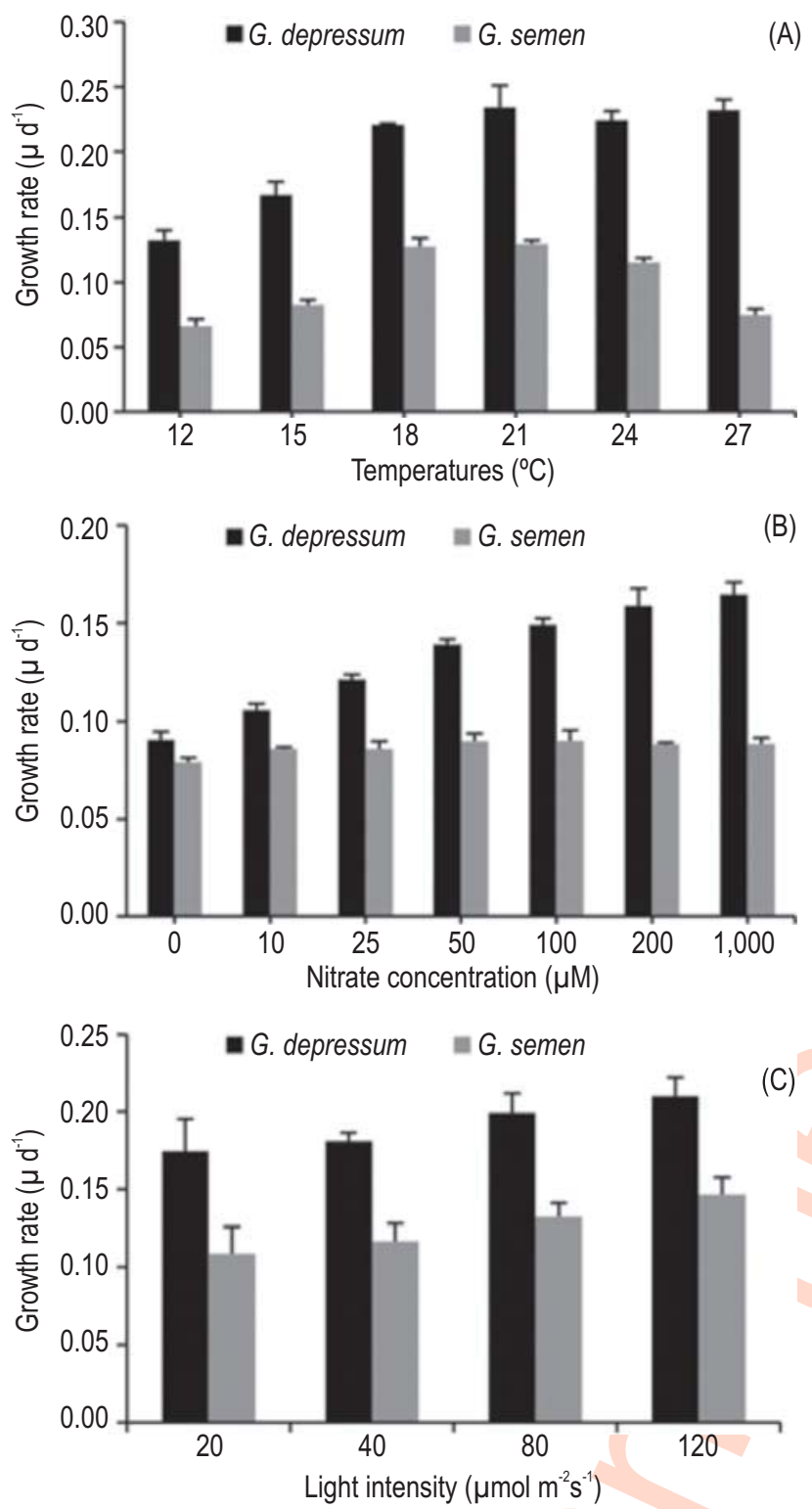

Fig. 3 : Population growth rates of $G$. depressum and $G$. semen $(A)$ at different temperatures, (B) different nitrate concentrations and (C) different light intensities

greatest at the highest tested level $\left(120 \mu\right.$ mol photons $\left.\mathrm{m}^{-2} \mathrm{~s}^{-1}\right)$ (Fig. $3 \mathrm{C}$ and 5).

G. depressum has a cosmopolitan distribution and can survive in a wide range of ecological conditions, variable temperature, conductivity, total phosphorus and ammonium content (Schmidt and Kusel-Fetzmann, 1999, sub "G. latum"). This species tolerates alkaline and warm water bodies, and occurs in waters with a temperature ranging from $13.4^{\circ} \mathrm{C}$ to $30.7^{\circ} \mathrm{C}$ (Schmidt and Kusel-Fetzmann, 1999, sub "G. latum"). In present study, temperature growth experiments clearly showed that population growth did not occur below $12^{\circ} \mathrm{C}$, and the optimum
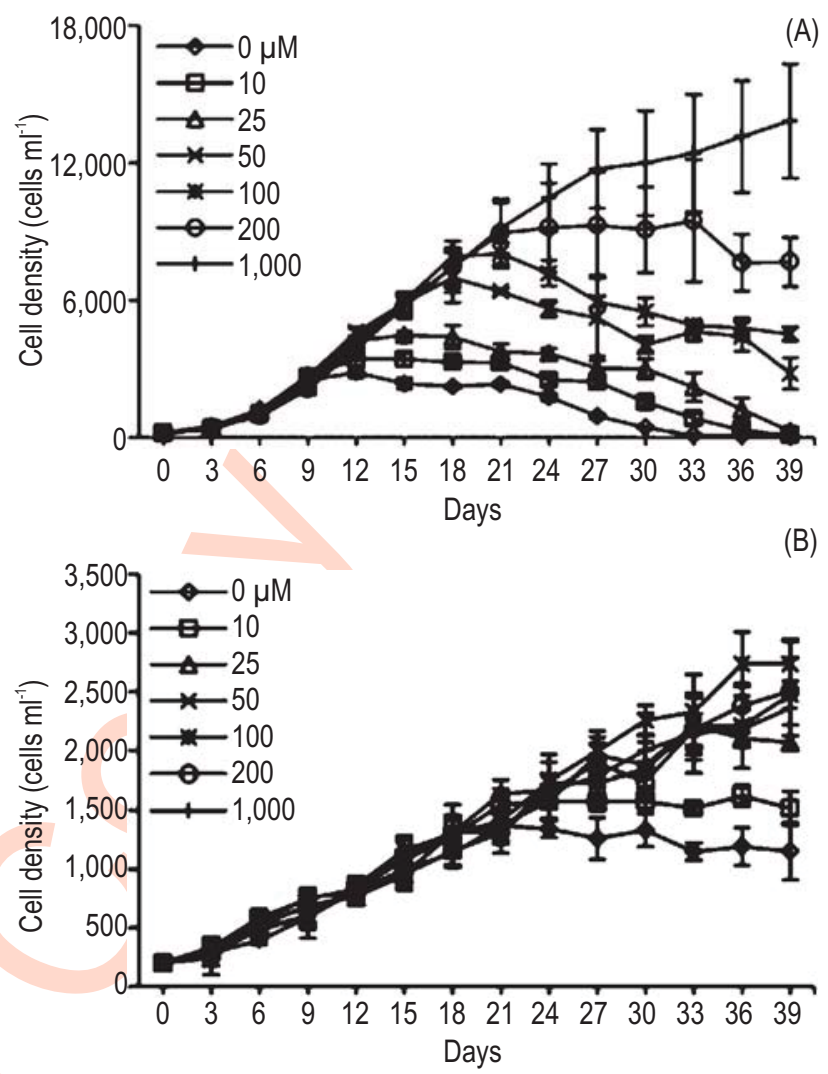

Fig. 4 : Population growth of $G$. depressum (A) and G. semen (B) at different nitrate concentrations

temperature for growth was between $18^{\circ} \mathrm{C}$ and $21^{\circ} \mathrm{C}$ (Fig. 2). Population growth occurred at wider range of nitrate concentrations (between 0 and $1,000 \mu \mathrm{M}$ ) than previous estimations (Schmidt and Kusel-Fetzmann, 1999, sub "G. latum"). The growth rate $(\mu)$ of this species gradually increased as nitrate concentration increased. In addition, population growth of $G$. depressum was greater as light intensity increased. These results showed that $G$. depressum is a photophilic species.

G. semen is characterized as an acidophilic and photophilic species mainly occurs in Sphagnum peat bog (Kusber, 2003). In Korea, this species occurs in various water bodies, but mostly in acidic mountainous bogs. This species forms blooms in various habitats in Europe (Willén, 2003; Findlay et al., 2005; Pęczuła, 2007), and these blooms are harmful for fish and human beings. Numerous field studies have examined factors that influence $G$. semen blooms, such as temperature, life cycle and light intensity (Figueroa and Rengefors, 2006; Rengefors et al., 2008, 2012; Hagman et al., 2015). Seasonal changes, such as increasing temperature and light intensity, stimulate germination of G. semen (Rengefors et al., 2012) and its biomass increases rapidly during the summer (Lebret et al., 2012). In the present study, the optimal growth temperature of $G$. semen was $18-21^{\circ} \mathrm{C}$. These results all in confirmation with the previous study of Rengefors et al. (2012), which revealed that 

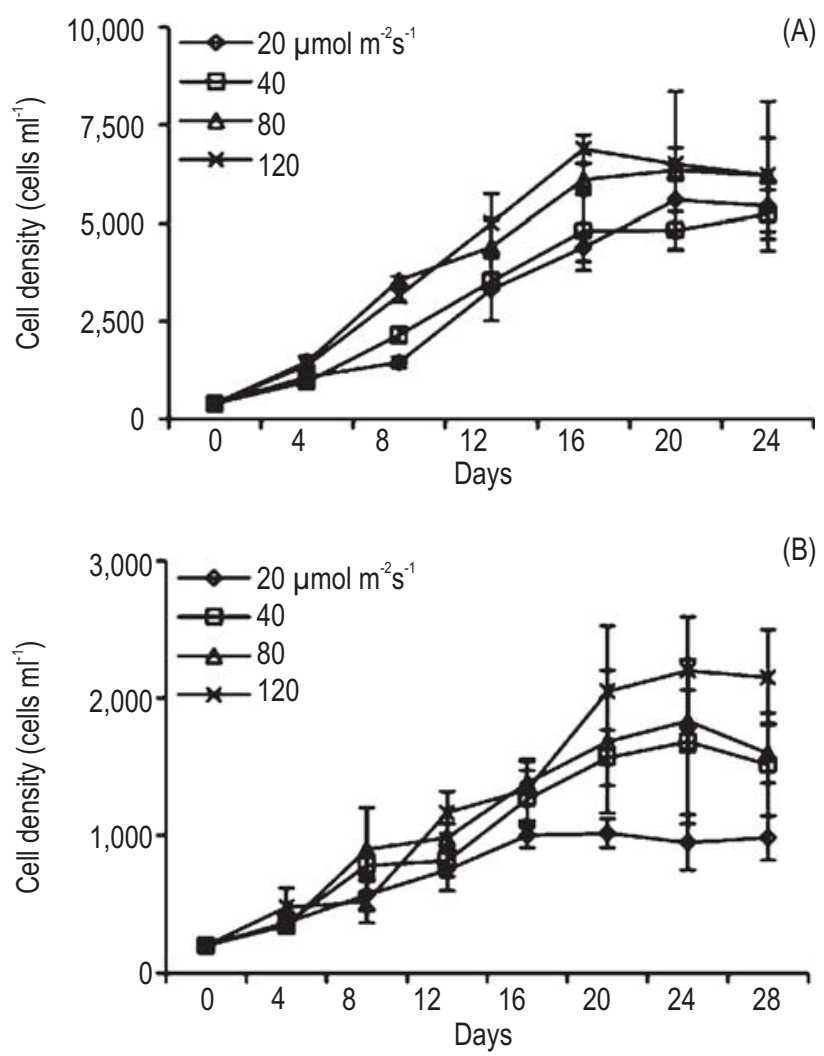

Fig. 5 : Population growth of $G$. depressum (A) and $G$. semen (B) at different light intensities

high temperature promotes bloom formation of $G$. semen. Moreover, nitrate concentration had little effect on the growth rate. The study concludes that the species showed best growth at high temperature and light intensity, and was little affected by nitrate concentration.

\section{Acknowledgment}

This work was supported by a grant from the National Institute of Biological Resources (NIBR), funded by the Ministry of Environment (MOE) of the Republic of Korea (NIBR201501209).

\section{References}

Bowers, H.A., C.Tomas, T. Tengs, J.W. Kempton, A.J. Lewitus and D.W. Oldach: Raphidophyceae [Chadefaud ex Silva] systematics and rapid identification: Sequence analyses and real-time PCR assays. J. Phycol., 42,1333-1348 (2006).

Cronberg, G.: The life cycle of Gonyostomum semen (Raphidophyceae). Phycologia, 44, 285-93 (2005).

Figueroa, R.I. and K. Rengefors: Life cycle and sexuality of the freshwater Raphidophyte Gonyostomum semen (Raphidophyceae). J. Phycology, 42, 859-871 (2006).

Findlay, D.L., M.J. Paterson, L.L. Hendzel and H.J. Kling: Factors influencing Gonyostomum semen blooms in a small boreal reservoir lake. Hydrobiology, 533, 243-252(2005).
Guiry, M.D. and M. Guiry: Algae Base. World-wide electronic publication, National University of Ireland, Galway. http://www.algaebase.org (2017).

Hagman, C.H.C., A. Ballot, D.Ø. Hjermann, B. Skjelbred, P. Brettum and R. Ptacnik: The occurrence and spread of Gonyostomum semen (Ehr.) Diesing (Rahpidophyceae) in Norwegian lakes. Hydrobiology, 744, 1-14 (2015).

Hehmann, A., L. Krienitz and D. Koschtel: Long-term phytoplankton changes in an artificially divided, top-down manipulated humic lake. Hydrobiology, 448, 83-96 (2001).

$\mathrm{Hu}, \mathrm{H}$. and Y. Wei: The freshwater algae of China. Systematics, taxonomy and ecology. Science Press, Beijing, China (2006).

Jo, B.Y., W. Shin, S.M. Boo, H.S. Kim and P.A. Siver: Studies on ultrastructure and three-gene phylogeny of the genus Mallomonas (Synurophyceae). J. Phycol., 47, 415-425 (2011).

Jo, B.Y., W. Shin, H.S. Kim, P.A. Siver and R.A. Andersen: Phylogeny of the genus Mallomonas (Synurophyceae) and descriptions of five new species on the basis of morphological evidence. Phycologia, 52, 266-278 (2013).

Kim, H.S.: Anabaena koreana sp. nov. (Cyanophyceae), a new species, and new record of fresh-water blue green algae from Korea. $J$. Ecol. Environ., 36, 293-302 (2013a).

Kim, H.S.: New record of fresh-water green algae (Chlirophytes) from Korea. J. Ecol. Environ., 36, 303-314 (2013b).

Kim, H.S.: New records of Euglenophyta from Korea. J. Ecol. Environ., 36, 339-346 (2013c).

Kim, H.S.: Desmids from Korea; 1. Desmidiaceae 1 (Micrasterias). J. Ecol. Environ., 37, 285-298 (2014a).

Kim, H.S.: Records of desmids (Chlorophyta) newly found in Korea. J. Ecol. Environ., 37, 299-313 (2014b).

Kim, J.H, Y.J. Park and H.S. Kim: Silica-scaled chrysophytes (Synurophyceae) from Jeju Island, Korea. Nova Hedwigia, 89, 201-218 (2009).

Korneva, L.G.: Ecological aspects of the mass development of Gonyostomum semen (Ehr.) Dies. (Raphidophyta). Algologia, 10, 265-277 (2000).

Kusber, W.H.: Typication of the four European species of Gonyostomum (Raphidophyceae) and first records of $G$. depressum from NE Germany. Willdenowia, 33, 467-474 (2003).

Lebret, K., M.F. Fernandez, C.H.C. Hagman, K. Rengefors and L.A. Hansson: Grazing resistance allows bloom formation and may explain invasion success of Gonyostomum semen. Limnol. Oceanogr., 57, 727-734 (2012).

Lebret, K., S.V.M. Tesson, E.S. Kritzberg, C. Tomas and K. Rengefors: Phylogeography of the freshwater Raphidophyte Gonyostomum semen confirms a recent expansion in Northern Europe by a single haplotype. J. Phycol., 51, 768-781 (2015).

Menezes, M. and C.E.M. Bicudo: Freshwater Raphidophyceae from the State of Rio de Janeiro, Southeast Brazil. Biota Neotrop., 10, 323331 (2010).

Negro, A.I., C. DeHoyos and J.C. Vega: Phytoplankton structure and dynamic in Lake Sanabria and Valparaiso reservoir (NW Spain). Hydrobiology, 424, 25-37 (2000).

Pęczuła, W.: Mass development of the algal species Gonyostomum semen (Raphidophyceae) in the meso humic Lake Płotycze (central-eastern Poland). Int. J. Oceanogr. Hydrobiol., 36, 163-172 (2007).

Rengefors, K., C. Pålsson, L.A. Hansson and L. Heiberg: Cell lysis of competitors and osmotrophy enhance growth of the bloom- 
forming alga Gonyostomum semen. Aquat. Microb. Ecol., 51, 8796 (2008).

Rengefors, K., G.A. Weyhenmeyer and I. Bloch: Temperature as a driver for the expansion of the microalga Gonyostomum semen in Swedish lakes. Harmful Algae, 18, 65-73 (2012).

Salonen, K. and M. Rosenberg: Advantages from diel vertical migration can explain the dominance of Gonyostomum semen (Raphidophyceae) in a small, steeply-stratified humic lake. J. Plankton Res., 22, 1841-1853 (2000).

Schmidt, A. and E. Kusel-Fetzmann: Weitere Datenzur Verbreitung von
Gonyostomum latum Ivanov in Europa, Afrika and Zentralamerika. (Further data to the distribution of Gonyostomum latum Ivanov in Europe, Africa and Central America). Algol. Stud., 92, 87-94 (1999).

Trigal, C., W. Goedkoop and R.K. Johnson: Changes in phytoplankton, benthic invertebrate and fish assemblages of boreal lakes following invasion by Gonyostomum semen. Freshwater Biology, 56, 1937-1948 (2011).

Willén, E.: Dominance patterns of planktonic algae in Swedish forest lakes. Hydrobiology, 502, 315-324 (2003). 